\title{
Generating Awareness for Different Therapeutic Diets in Rural Bulandshahr, Uttar Pradesh: Application of Difference in Differences Method
}

\author{
Kirti M. Tripathi ${ }^{1 *}$, Kalpana Sharma ${ }^{2}$, Laxmikant ${ }^{1}$, Savita Arya $^{2}$, \\ Sarita Joshi ${ }^{2}$ and Bina Yadav ${ }^{2}$ \\ ${ }^{1} K V K$, Bulandshahr, India \\ ${ }^{2}$ Ginni Modi College, Ghaziabad, KVK, Mujaffarnagar, KVK, Baghpat, KVK, Meerut, India \\ *Corresponding author
}

\section{Keywords}

Awareness generation,

Knowledge,

Difference in

Differences,

Therapeutic diets

Article Info

Accepted:

12 June 2021

Available Online:

10 July 2021
Non communicable diseases are the major issues which needs to be identified in terms of prevalence, health hazards, lifestyle change, unbalanced diet, physical disparity, physiological and mental changes and unawareness etc. This has resulted into the adverse effect on human health. Incidences of hypertension, type II diabetes, osteoporosis and gout/ arthiritis have been elevated by 18.2 per cent since last decade in India. The study was conducted to precisely estimate the effect of trainings imparted to 100 rural women with respect to different parameters of environment, different non communicable diseases and therapeutic diets with respect to them. The methodology used in finding out the output was "difference in differences" method. For the purpose 100 women farmers were also sampled as control group. The study is considered as random controlled trial. The pre training mean score of treatment (PrTMS-T) group on their overall awareness about different parameters of environment, therapeutic diets, different ailments and there dietary management was 1.18 which increased to 1.88 in post- training survey (PoTMS-T) and it was found to be very effective with mean score of main effect of training (MSMET) 0.74 over control. It was concluded from the study that well defined training programmes shall definitely bring a major transformation in awareness level of rural women. Moreover, the methodology used also got validated in the study which opened a new option for the extension researchers to precisely estimate the effect of any planned intervention.

\section{Introduction}

Human brain is advancing, highest technologies in every sphere of life is proving it. "We are what we eat", is an old saying, which perceives the significance of food which is consumed. Lack of awareness is very prominent when it comes to food security and 
persisting beliefs of traditional knowledge is making it even narrower (Antonio and Jagjit, 2017).

Rakely supervised nutritional program and inappropriate public food dispersion system are the unhidden factors hindering food security of India (Prakash and Palanivel, 2011).

Unawareness related to food is causing serious health issues in young children. Stunted growth, malnutrition and micronutrient deficiency diseases are prevailing abruptly (Manpreet and Amitha, 2008).

All the stakeholders such as government, scientists, concerned people at home should be nutritionally educated so that access to nutritious diets, clean environment and healthy lifestyle should be promoted (Gopalan, 2013).

It is evident that modifications of diets in different ailments like diabetes, hypertension, gout, osteoarthritis etc. prepositioned a major impact in human life. Better dietary knowledge, perception and improvised package leads to better understanding and control of diseases (Waqas Sami, 2017).

Edward, 2017 in his study concluded that there is a significant difference in dietary pattern of rural and urban population of India. There is an increase in total energy intake and salt consumption. Urban population is much on the verge of becoming obese, hypertensive and other diseases. Research suggested that there is supposed to be detrimental effects on overall health in concordance with dietary changes in India.

A therapeutic diet is usually moderation of regular diet. Usually modifications are inculcated in nutrients taking in consideration of disease pertaining. National Institute of Nutrition says that clinical management is possible with therapeutic diets. Focus is laid on underlying conditions of patients history, existing symptoms and present condition of the patient.

Nutrition sensing and absorption of energy plays vital role in improving quality of life, it also controls ageing and life expectancy. Diets comparatively low in fats, high in fiber too mark their presence in upbringing greater life expectancy and combating illness (Sridhar, 2015).

Awareness generation programme does create the change in perception of people towards different diseases. Ankit Chandra et al., (2016) in his study concluded that the intervention of such awareness programs increases the knowledge upto $62.8 \%$, though there was a devaluation in the viewpoint and the interest of the people towards alleviating care of HIV/ AIDS patients.

Awareness is very low regarding the prevention, control and treatment of different therapeutic diseases. Even the people are not aware about the existing illness. In one study of 731864 individuals, $76.1 \%$ were screened in which $44.7 \%$ were aware of diagnosis and $13.3 \%$ were treated and only $7.9 \%$ achieved control on the illness (Prenissl, et al., 2019). Difference in differences design can be used as public health policy research tool. It is a quasi- experimental design and represents a feasible tool to acquire more about causal relationship. It removes the space and time biasness between the two groups tested in two different times. It can be used in applied sciences to validate the assumptions (Coady Wing et al., 2018).

\section{Materials and Methods}

The present study was conducted in rural arena of Bulandshahr district which is located in western Uttar Pradesh. Total of 200 rural 
females of age group 20- 40 years were randomly selected exclusive the criteria of education. Two groups namely treatment group and control group were made including 100 females in each group. In both the groups, again four groups of 25 females were made.

These small groups were made purposely so that, imparting training would be easy and comfortable and interaction could be made convenient. A non- prompted questionnaire was prepared to ask the questions regarding climate change and therapeutic diets, different components of hypertension, type II diabetes, osteoporosis and gout/ arthritis.

Pre training survey was conducted in July 2019 and questions were asked regarding awareness of different parameters of therapeutic diets. Again, in November 2019 post training survey was carried out and same questions were taken into consideration. The score was calculated on 3 continuums i.e. most knowledgeable, moderately knowledgeable and unknowledgeable in pre survey. In post survey again 3 continuums were proclaimed namely most acquired/ moderately acquired and unacquired.

As the training needs should also be prioritized so to give them consolidated score frequency of the respondents was multiplies with their respective continuum score and summation was done afterwards. Mean score of pre- training and post- training was calculated and then subtracted for treatment and control group.

To find out main effect of the training again, subtraction was conducted between already subtracted mean scores of pre- and posttrainings of both treatment and control groups. Paired t- test of two sample means was carried out to see the significant difference in pre- and post-training of both the groups. The methodology used was Difference in differences (Zhou, et al., 2016, Kirti et al., 2020) which makes the design so appropriate to find out the differential effect of the training imparted. It is a strong analytical tool which proved to be helpful in removing time and space biases. This tool minimises the effect of extraneous variables.

\section{Results and Discussion}

In the procedure of transmitting trainings on different topics of awareness it was found that women were very much affected by social restraints like food is just food and it is consumed to fulfil the hunger. Myths pursuing in rural areas were limiting the respondents to accept the different certitudes related to different diseases and their dietary treatment.

In the post- training survey, it was assessed that extent of acquaintance, knowledge and awareness was enhanced among respondents.

Climate change and therapeutic diets are the most significant domain wherein rural women require meticulous awareness through training subjection for their cognitive enhancement.

Second most emphasised areas are different components of hypertension followed by diabetes followed by osteoporosis, emerging out due to change in lifestyle even at rural level wherein rural women require comprehension backstopping. Different components of gout/ arthritis and the dietary management did not appear as the notable sector.

Therefore, to sustain the knowledge of rural women, deliberate awareness is needed. Total awareness score and mean score were calculated with a purpose that further tutoring is required in some areas like awareness about global warming, hypertension and its causes followed by type II diabetes and its causes, osteoporosis and its causes further followed by gout/ arthritis as a whole topic. 
Table.1 Overall effect of training on different parameters

\begin{tabular}{|c|c|c|c|c|c|c|c|c|}
\hline \multirow{2}{*}{$\begin{array}{l}\text { Sl. } \\
\text { No. }\end{array}$} & \multirow{2}{*}{ Awareness about } & \multirow{2}{*}{$\begin{array}{l}\text { Total } \\
\text { acquisition } \\
\text { Score } \\
\text { (TAS) }\end{array}$} & \multicolumn{2}{|c|}{ Treatment group } & \multicolumn{2}{|c|}{ Control group } & \multirow{2}{*}{$\begin{array}{c}\text { Main effect } \\
\text { of the } \\
\text { training } \\
\text { (B-A) -(D-C) } \\
\text { (MSMET) }\end{array}$} & \multirow[t]{2}{*}{ t-value } \\
\hline & & & $\begin{array}{c}\text { Pre-training MS } \\
\text { (A) } \\
\text { (PreTMST) }\end{array}$ & $\begin{array}{c}\text { Post-training MS } \\
\text { (B) } \\
\text { (PostTMST) }\end{array}$ & $\begin{array}{c}\text { Before } \\
\text { training MS } \\
(\mathrm{C}) \\
\text { (PreTMSC) }\end{array}$ & $\begin{array}{c}\text { After } \\
\text { training MS } \\
\text { (D) } \\
\text { (PreTMSC) }\end{array}$ & & \\
\hline a) & $\begin{array}{l}\text { Environment and } \\
\text { Therapeutic diets }\end{array}$ & 424 & 1.10 & 2.07 & 1.09 & 1.17 & 0.92 & $2.39 *$ \\
\hline b) & Hypertension & 375 & 1.26 & 2.14 & 1.22 & 1.30 & 0.80 & $2.11 * *$ \\
\hline c) & Type II Diabetes & 373 & 1.21 & 1.94 & 1.21 & 1.28 & 0.66 & $1.84 * *$ \\
\hline d) & Osteoporosis & 372 & 1.16 & 1.18 & 1.16 & 1.21 & 0.61 & $1.70^{* *}$ \\
\hline e) & Gout/Arthritis & 284 & 1.11 & 1.65 & 1.11 & 1.16 & 0.47 & $1.16^{\mathrm{NS}}$ \\
\hline f) & Malnutrition & 431 & 1.25 & 2.27 & 1.22 & 1.29 & 0.97 & $2.53 *$ \\
\hline & Average & 377 & 1.18 & 1.88 & 1.16 & 1.24 & 0.74 & $2.03^{* *}$ \\
\hline
\end{tabular}

*significant at $\mathrm{p}<0.01, * *$ significant at $\mathrm{p}<0.05$

Overall effect of training intervention: Table 1 on overall effect of training depicted that awareness on different parameters of malnutrition (MSMET 0.97) and environment and therapeutic diets (MSMET 0.92) were found to be most significant ( $p>0.01$ ) in terms of knowledge acquisition. Cognizance about hypertension (MSMET 0.80), type ii diabetes (MSMET 0.66) followed by osteoporosis were also found to be significant ( $p>0.05$ ). The PrTMS-T of diet modification in different weather was 1.11 which was already low in comparison of other topics. The PoTMS-T of same was recorded as 1.65 but as the respondents did not acquire much knowledge in related parameters so the results reflected as non-significant (MSMET 1.16). 
Table.2 Effect of training on different components of environment and therapeutic diets

\begin{tabular}{|c|c|c|c|c|c|c|c|c|}
\hline \multirow{2}{*}{$\begin{array}{l}\text { Sl. } \\
\text { No. }\end{array}$} & \multirow{2}{*}{$\begin{array}{c}\text { Awareness } \\
\text { about }\end{array}$} & \multirow{2}{*}{$\begin{array}{c}\text { Total } \\
\text { acquisition } \\
\text { Score } \\
\text { (TAS) }\end{array}$} & \multicolumn{2}{|c|}{ Treatment group } & \multicolumn{2}{|c|}{ Control group } & \multirow{2}{*}{$\begin{array}{c}\text { Main effect of } \\
\text { the training } \\
(\text { B-A })-(D-C)\end{array}$} & \multirow[t]{2}{*}{ t-value } \\
\hline & & & $\begin{array}{c}\text { Pre-training } \\
\text { MS } \\
\text { (A) }\end{array}$ & $\begin{array}{l}\text { Post-training } \\
\text { MS } \\
\text { (B) }\end{array}$ & $\begin{array}{l}\text { Before training MS } \\
\text { (C) }\end{array}$ & $\begin{array}{l}\text { After training MS } \\
\text { (D) }\end{array}$ & & \\
\hline a) & Environment & $415(\mathrm{IV})$ & 1.00 & 1.85 & 1.01 & 1.08 & 0.78 & $1.93 * *$ \\
\hline b) & Global Warming & $404(V)$ & 1.12 & 1.76 & 1.10 & 1.14 & 0.60 & $1.53^{\mathrm{NS}}$ \\
\hline c) & Pollution & 421(III) & 1.04 & 2.00 & 1.02 & 1.12 & 0.86 & $2.36^{*}$ \\
\hline d) & Balanced Diets & 436(II) & 1.12 & 2.25 & 1.14 & 1.21 & 1.06 & $2.51 *$ \\
\hline e) & $\begin{array}{c}\text { Therapeutic } \\
\text { diets }\end{array}$ & $444(I)$ & 1.23 & 2.62 & 1.20 & 1.31 & 1.28 & $2.63^{*}$ \\
\hline & Average & 424 & 1.10 & 2.10 & 1.09 & 1.17 & 0.92 & $2.39 *$ \\
\hline
\end{tabular}

*significant at $\mathrm{p}<0.01, * *$ significant at $\mathrm{p}<0.05$

Table 3 demonstrated the effect of training on different components of environment and therapeutic diets. Awareness on environment, global warming, pollution, balanced diets and therapeutic diets was generated among rural women. Awareness acquainted about therapeutic diets was found to be maximum with MSMET 1.28. Balanced diets and its effect on health were perceived on second position followed by pollution and environment with MSMET $1.06,0.86$ and 0.78 respectively. They were found to be significant $\mathrm{p}>0.01$ at $199 \mathrm{df}$ except environment which was found significant at $\mathrm{p}>0.05$. Awareness on global warming was observed to be non-significant. Global warming was least acquainted topic as we can see that PrTMS-T was1.12 which was quite low and PoTMS-T, increased to 1.76 and it needs to be taken into consideration again. 
Table.3 Effect of training on different components of Hypertension

\begin{tabular}{|c|c|c|c|c|c|c|c|c|}
\hline \multirow{2}{*}{$\begin{array}{l}\text { Sl. } \\
\text { No. }\end{array}$} & \multirow[t]{2}{*}{ Awareness about } & \multirow{2}{*}{$\begin{array}{c}\text { Total } \\
\text { acquisition } \\
\text { Score } \\
\text { (TAS) }\end{array}$} & \multicolumn{2}{|c|}{ Treatment group } & \multicolumn{2}{|c|}{ Control group } & \multirow{2}{*}{$\begin{array}{l}\text { Main effect of } \\
\text { the training } \\
\text { (B-A) -(D-C) }\end{array}$} & \multirow[t]{2}{*}{ t-value } \\
\hline & & & $\begin{array}{l}\text { Pre-training } \\
\text { MS } \\
\text { (A) }\end{array}$ & $\begin{array}{l}\text { Post-training MS } \\
\text { (B) }\end{array}$ & $\begin{array}{l}\text { Before training } \\
\text { MS (C) }\end{array}$ & $\begin{array}{l}\text { After training } \\
\text { MS (D) }\end{array}$ & & \\
\hline a) & Hypertension & 357 & 1.31 & 1.91 & 1.11 & 1.23 & .48 & $1.04^{\mathrm{NS}}$ \\
\hline b) & $\begin{array}{l}\text { Foods avoided in } \\
\text { Hypertension }\end{array}$ & 376 & 1.32 & 2.42 & 1.30 & 1.39 & 1.01 & $2.46^{*}$ \\
\hline c) & $\begin{array}{c}\text { Causes of } \\
\text { Hypertension }\end{array}$ & 320 & 1.26 & 1.76 & 1.28 & 1.34 & 0.44 & $1.01^{\mathrm{NS}}$ \\
\hline d) & $\begin{array}{l}\text { Therapeutic diet in } \\
\text { hypertension }\end{array}$ & 362 & 1.11 & 1.94 & 1.14 & 1.21 & 0.76 & $2.13 * *$ \\
\hline \multirow[t]{2}{*}{ e) } & $\begin{array}{c}\text { Importance of } \\
\text { physical activities }\end{array}$ & 462 & 1.28 & 2.68 & 1.26 & 1.30 & 1.36 & $2.83 *$ \\
\hline & Average & 375 & 1.26 & 2.14 & 1.22 & 1.29 & 0.81 & $2.11 * *$ \\
\hline
\end{tabular}

*significant at $\mathrm{p}<0.01, * *$ significant at $\mathrm{p}<0.05$

Effect on training on different components of hypertension was found to be significant with MSMET $0.81, \mathrm{p}>0.05$ at 199 df. Importance of physical activities and related parameters like types of activities etc. were well accepted with MSMET 1.36. Knowledge about foods to be avoided in hypertension and its recommended daily allowances was also properly acquired by respondents (MSMET 1.01). Respondents were already had little acquaintance about therapeutic diet in hypertension, timings of meals and interval between two meals hypertension etc. The PrTMS-T was recorded as 1.11 and later as 1.94 . Knowledge for hypertension and its related terminology, its various causing factors and maintenance was established as non-significant and this topic need to be emphasised again (Table 3 ). 
Table.4 Effect of training on different components of Type II Diabetes

\begin{tabular}{|c|c|c|c|c|c|c|c|c|}
\hline \multirow{2}{*}{$\begin{array}{l}\text { Sl. } \\
\text { No. }\end{array}$} & \multirow[t]{2}{*}{ Awareness about } & \multirow{2}{*}{$\begin{array}{c}\text { Total } \\
\text { acquisition } \\
\text { Score } \\
\text { (TAS) }\end{array}$} & \multicolumn{2}{|c|}{ Treatment group } & \multicolumn{2}{|c|}{ Control group } & \multirow{2}{*}{$\begin{array}{l}\text { Main effect of } \\
\text { the training } \\
(B-A)-(D-C)\end{array}$} & \multirow[t]{2}{*}{ t-value } \\
\hline & & & $\begin{array}{c}\text { Pre-training } \\
\text { MS (A) }\end{array}$ & $\begin{array}{l}\text { Post-training MS } \\
\text { (B) }\end{array}$ & $\begin{array}{c}\text { Before } \\
\text { training MS } \\
\text { (C) }\end{array}$ & $\begin{array}{l}\text { After } \\
\text { training MS } \\
\text { (D) }\end{array}$ & & \\
\hline a) & Type II Diabetes & 366 & 1.19 & 1.84 & 1.20 & 1.29 & 0.56 & $1.27^{\mathrm{NS}}$ \\
\hline b) & $\begin{array}{c}\text { Causes of Type II } \\
\text { Diabetes }\end{array}$ & 291 & 1.09 & 1.50 & 1.11 & 1.17 & 0.35 & $1.02^{\mathrm{NS}}$ \\
\hline c) & $\begin{array}{l}\text { Foods to be avoided } \\
\text { in Type II Diabetes }\end{array}$ & 401 & 1.26 & 2.11 & 1.27 & 1.32 & 0.80 & $2.17 * *$ \\
\hline d) & $\begin{array}{l}\text { Therapeutic diet in } \\
\text { Type II Diabetes }\end{array}$ & 432 & 1.17 & 2.21 & 1.19 & 1.25 & 0.98 & $2.39 *$ \\
\hline \multirow[t]{2}{*}{ e) } & $\begin{array}{c}\text { Importance of } \\
\text { physical activities }\end{array}$ & 377 & 1.32 & 2.02 & 1.27 & 1.38 & 0.59 & $1.33 * *$ \\
\hline & Average & 373 & 1.21 & 1.94 & 1.21 & 1.28 & 0.66 & $1.84 * *$ \\
\hline
\end{tabular}

*significant at $\mathrm{p}<0.01, * *$ significant at $\mathrm{p}<0.05$

Table 8 depicted effect of training on different components of type II diabetes. Rural generation got more aware about the modifications in diet to be made in the topic therefore most of the results were recorded as significant $(\mathrm{p}>0.01)$. Awareness on foods inclusion and exclusionand importance of physical activities was acquired proficiently thus results came significant $(\mathrm{p}>0.05)$. The science behind reasons of occurance of diabetes and physiological changes were still not well acquainted thus the results portrayed as non-significant. The overall extent of awareness was significant ( $p>0.05$ ) as can be evident( MSMET- 0.66). 
Table.5 Effect of training on different components of Osteoporosis

\begin{tabular}{|c|c|c|c|c|c|c|c|c|}
\hline \multirow{2}{*}{$\begin{array}{l}\text { Sl. } \\
\text { No. }\end{array}$} & \multirow[t]{2}{*}{ Awareness about } & \multirow{2}{*}{$\begin{array}{c}\text { Total } \\
\text { acquisition } \\
\text { Score } \\
\text { (TAS) }\end{array}$} & \multicolumn{2}{|c|}{ Treatment group } & \multicolumn{2}{|c|}{ Control group } & \multirow{2}{*}{$\begin{array}{c}\text { Main effect } \\
\text { of the } \\
\text { training } \\
\text { (B-A) -(D-C) }\end{array}$} & \multirow[t]{2}{*}{ t-value } \\
\hline & & & $\begin{array}{c}\text { Pre-training } \\
\text { MS } \\
\text { (A) }\end{array}$ & $\begin{array}{l}\text { Post-training MS } \\
\text { (B) }\end{array}$ & $\begin{array}{c}\text { Before } \\
\text { training MS } \\
\text { (C) }\end{array}$ & $\begin{array}{c}\text { After } \\
\text { training MS } \\
\text { (D) }\end{array}$ & & \\
\hline a) & Osteoporosis & 301 & 1.19 & 1.46 & 1.20 & 1.24 & 0.23 & $0.92^{\mathrm{NS}}$ \\
\hline b) & $\begin{array}{c}\text { Causes of } \\
\text { osteoporosis }\end{array}$ & 342 & 1.14 & 1.74 & 1.13 & 1.16 & 0.57 & $1.23^{\mathrm{NS}}$ \\
\hline c) & $\begin{array}{l}\text { Foods to be included } \\
\text { in osteoporosis }\end{array}$ & 435 & 1.19 & 2.15 & 1.20 & 1.25 & 0.91 & $2.43 *$ \\
\hline d) & $\begin{array}{c}\text { Therapeutic diet in } \\
\text { osteoporosis }\end{array}$ & 372 & 1.15 & 1.85 & 1.17 & 1.23 & 0.64 & $1.72 * *$ \\
\hline e) & $\begin{array}{c}\text { Importance of } \\
\text { physical activities }\end{array}$ & 411 & 1.12 & 1.86 & 1.10 & 1.16 & 0.68 & $1.81 * *$ \\
\hline & Average & 372 & 1.16 & 1.81 & 1.16 & 1.21 & 0.61 & $1.70 * *$ \\
\hline
\end{tabular}

*significant at $\mathrm{p}<0.01, * *$ significant at $\mathrm{p}<0.05$

Awareness about food sources and precautions regarding the dietary management was critically accepted by respondents with MSMET 0.91. Women usually had

misconception about the symptoms of osteoporosis and coincide the osteoporosis with gout/ arthiritis. So during the awareness generation session clarity on the point was made. Although, the scientific concept of topic and its causing factors was not really clear to them (statistically found non-significant). Awareness generation about therapeutic diet and importance of physical activities in osteoporosis was identified as significant $\mathrm{p}>0.05$ (Table 6). 
Table.6 Effect of training on different components of Gout/Arthritis

\begin{tabular}{|c|c|c|c|c|c|c|c|c|}
\hline \multirow{2}{*}{$\begin{array}{l}\text { Sl. } \\
\text { No. }\end{array}$} & \multirow[t]{2}{*}{ Awareness about } & \multirow{2}{*}{$\begin{array}{c}\text { Total } \\
\text { acquisition } \\
\text { Score } \\
\text { (TAS) }\end{array}$} & \multicolumn{2}{|c|}{ Treatment group } & \multicolumn{2}{|c|}{ Control group } & \multirow{2}{*}{$\begin{array}{l}\text { Main effect of } \\
\text { the training } \\
(B-A)-(D-C)\end{array}$} & \multirow[t]{2}{*}{ t-value } \\
\hline & & & $\begin{array}{c}\text { Pre-training } \\
\text { MS } \\
\text { (A) }\end{array}$ & $\begin{array}{l}\text { Post-training MS } \\
\text { (B) }\end{array}$ & $\begin{array}{c}\text { Before } \\
\text { training MS } \\
\text { (C) }\end{array}$ & $\begin{array}{l}\text { After } \\
\text { training MS } \\
\text { (D) }\end{array}$ & & \\
\hline a) & Gout/ Arthritis & 231 & 1.26 & 1.48 & 1.32 & 1.39 & 0.15 & $0.83^{\mathrm{NS}}$ \\
\hline b) & $\begin{array}{c}\text { Causes of Gout/ } \\
\text { Arthritis }\end{array}$ & 246 & 1.32 & 1.55 & 1.26 & 1.27 & 0.22 & $0.85^{\mathrm{NS}}$ \\
\hline c) & $\begin{array}{c}\text { Foods to be included } \\
\text { and avoided }\end{array}$ & 295 & 1.28 & 1.78 & 1.24 & 1.29 & 0.5 & $1.02 * *$ \\
\hline d) & $\begin{array}{l}\text { Therapeutic diet in } \\
\text { Gout/ Arthritis }\end{array}$ & 215 & 1.15 & 1.28 & 1.16 & 1.17 & 0.12 & $0.72^{\mathrm{NS}}$ \\
\hline e) & $\begin{array}{c}\text { Importance of } \\
\text { physical activities }\end{array}$ & 298 & 1.11 & 1.63 & 1.13 & 1.15 & 0.5 & $1.05 * *$ \\
\hline & Average & 257 & 1.22 & 1.52 & 1.22 & 1.25 & 0.30 & $0.94^{\mathrm{NS}}$ \\
\hline
\end{tabular}

*significant at $\mathrm{p}<0.01, * *$ significant at $\mathrm{p}<0.05$

Awareness about different components of gout/arthiritis and its different aspects was found to be non-significant. During study it was seen that topic above was found to be little strenuous in terms of awareness generation. Women were initially less aware about the topic. Foods to be consumed and avoided and importance of physical activities in the subject were established most significant and

well acquired by the respondents with MET 0.50 respectively. The PrTMS-T of therapeutic diet was 1.15 and after training it was 1.28 which was relatively very less in terms of awareness generation. Therefore, few of the most important aspect of gout/arthiritis were identified as non-significant. Further backstopping is essential in these 3 topics (Table 5). 


\section{References}

Ankit Chandra, Sonali Sarkar, S. Adinarayanan and Saksham Balajee, Impact of Health Awareness Campaign in improving the perception of the community about Palliative Care: A preand post study In rural Tamil Nadu, Indian J Palliat Care., 22(4) (2016) 467476.doi: 10.4103/0973-1075.191832.

Antonia. Marika. Vicziany, JagjitPlahe, Food security and traditional knowledgein India: The issues. South Asian journal of south Asian studies., 40(3)(2017) 566581 ,

Coady Wing, Kosali Simon and Ricardo A. Bello- Gomez, Designing Difference in difference Studies: Best Practices for Public Health Policy Research. Annual Review of Public Health., 39 (2018) 453-69. https://doi.org/10.1146/annurevpublhealth. 040617-013507.

doi: 10.1080/00856401.2017.7342181.

Edward J. M. Joy, Rosemary Green, Sutapa Agarwal et al., Dietary patterns and noncommunicable disease risk in Indian adults: secondary analysis of Indian Migration study data, Public Health Nutr., 20(11) (2017) 1963-1972. doi: 10.1017/ S1368980017000416.

Gopalan, C, The changing nutrition scenario. Indian J Med Res., 138(3) (2013) 392397.

Kirti M. Tripathi and S. K. Dubey,Generating Awareness for Health Hazards of Climate Change in Rural Western Uttar Pradesh, India: Application of
Difference-in-Differences Method. Indian Journal of Extension Education 56(1) (2020) 122-127.

Manpreet Kaur and Amitha M Hegde, Are we aware of what we are, we are what we eat- An Epidemiological Survey. Int J Clin Pediatr Dent., 1(1) (2008) 13-16. doi: 10.5005/jp-journals-10005-1003

Prakash Upadhyay, R and C Palanivel, Challenges in Achieving Food Security in India. Inran J Public Health., 40(4) (2011) 31-36.

Prenissl J, Manne- Goehler J, Jaacks LM, Prabhakaran D, Awasthi A, et al., Hypertension screening, awareness, treatment and control in India: A nationally representative cross-sectional study among individuals aged 15 to 49 years, PLOS Medicine., 16(5)(2019) e1002801.

Shridhar G. Rajendra N, Murigendra. H, Shridevi $\mathrm{P}$ et al., Modern Diet and its impact on Human Health. Journal of Nutrition and Food science., 5(6) (2015) doi: 10.4172/2155-9600.1000430.

Waqas Sami, Tahir Ansari, Nadeem Shafique Butt and Mohd Rashid Ab Hamid, Effect of diet on type 2 diabetes mellitus: A review. International Journal of Health Sciences., 11(2) (2017) 65-71.

Zhou, H., et al., Difference-in-Differences Method in Comparative Effectiveness Research: Utility with Unbalanced Groups, Applied Health Economics and Health Policy. 14 (2016) 419-429.

\section{How to cite this article:}

Kirti M. Tripathi, Kalpana Sharma, Laxmikant, Savita Arya, Sarita Joshi and Bina Yadav. 2021. Generating Awareness for Different Therapeutic Diets in Rural Bulandshahr, Uttar Pradesh: Application of Difference in Differences Method. Int.J.Curr.Microbiol.App.Sci. 10(07): 89-98. doi: https://doi.org/10.20546/ijcmas.2021.1007.010 